\title{
THE INFLUENCE OF ORGANIZATIONAL CULTURE AND WORK MOTIVATION ON THE PERFORMANCE OF BHAYANGKARA MEMBERS, COMMUNITY SERVICES AND PUBLIC ORDER UNIT OF BUNGO RESORT POLICE
}

\author{
${ }^{1}$ Novi Indah Earlyanti, ${ }^{2}$ Bobi Subasri \\ ${ }^{1}$ Police Science College, Jakarta, Indonesia, earlyantinovember24@ gmail.com, ${ }^{2}$ Jambi Police \\ Region, Jambi, Indonesia, bobysubasri@gmail.com
}

Citation: Novi Indah Earlyanti and Bobi Subasri, The Influence Of Organizational Culture And Work Motivation On The Performance Of Bhayangkara Members, Community Services And Public Order Unit Of Bungo Resort Police, Management Technology and Security International Journal, pages : 137-152, https://doi.org/10.47490/mtsij.v1.i2.137152

Received on 7 September 2020, Accepted on 20 October 2020, Published on 1 November 2020

\begin{abstract}
Performance can be interpreted as an extra role such as cooperation, helping colleagues and superiors, and contributing to organizational goals. Culture in an organization can improve performance, because it can create positive motivation to give the best ability to the organization. This study is looking at the influence of organizational culture and work motivation on performance. Organizational culture is defined as the way a person behaves in an organization, and work motivation is the achievement that someone produces because of a drive to complete work in the most possible effective and efficient time to get better results and be able to adjust to the work climate. The purpose of this study is to determine the effect of organizational culture and work motivation on the performance of the members of Bhabinkamtibmas (a police sergeant responsible for establishing and maintaining security and public order in a village) of Resort Police. This research uses quantitative approach with survey method. The population in this study are 53 members of Bhabinkamtibmas of Bungo Resort Police, using total sampling. The data collection technique uses questionnaire consisting of 45-statement items, which are from 9 indicators, and the measurement uses Likert scale with the answer range of 1 to 5. The results show that organizational culture has a significant effect of $93.7 \%$ on performance variable and work motivation has a significant effect of $87.4 \%$ on the performance variable. Therefore, it can be explained that the organizational culture variable (X1) has a greater influence on the performance variable (Y) than the motivation variable (X2). Organizational culture and motivation simultaneously provide a significant influence of $94.1 \%$ on the performance. Performance can be improved if the organizational culture is healthy, thus can increase the motivation of members.
\end{abstract}

Key words: corruption, culture, motivation, performance

\section{INTRODUCTION}

The village administration serves as the gateway between villagers and the central government in the context of village development. Based on the Government Regulation Number 22/ 2015 , the source of village development fund comes from the State Revenue and Expenditure Budget (APBN) which is transferred in stages through the 
Regency/City Revenue and Expenditure Budget by $10 \%$. The realization of the distribution of village fund from 20152017 continued to increase, whereby in 2015 the fund distributed was around IDR 772.6 million/ village, in 2016 the distribution was IDR. 1.140 billion/ village, and in 2017 was IDR 1,285 billion/ village.

From the results of a study conducted by the Corruption Eradication Commission (KPK) in 2014, it was found that there were several problems in the management of village fund related to its allocation, including the aspects of regulation, management, supervision and human resources (Agung, 2015). To supervise the management of village fund so that they are not misused, authority is given to Bhabinkamtibmas officers who become the village partners to oversee the use of the village fund budget. Warsono and Ruksamin (2014) state that the management of village fund will not be carried out properly if the following occurs: low community role, poor management, low level of supervision, and no evaluation of the activities.

The position of Bhabinkamtibmas members is as the frontline in providing police services to the community at the village level. They are the village partner and first line of direct contact to the community. During the current Covid-19 pandemic, the presence of community services members is necessary. Extra work is required from the members of Bhabinkamtibmas as the front-liner of police service. Apart from escorting the use of village fund, they are also required to socialize the Covid-19 health protocols, which are currently entering the New Normal era. This is a form of support for the budget revision program of the Minister of Villages, Development of Disadvantaged Areas and Transmigration, namely the priority of strengthening the village economy and strengthening public health (kompas.com).

This has led to an increase in the work load of Bhabinkamtibmas members, because they oversee the use of village fund for infrastructure development and they are also required to monitor the implementation of 'Village Response to Covid-19' which may allow the village fund manipulation to happen. The high work demand of Bhabinkamtibmas members are expected to receive higher support from the organization and attention from the organizational leaders for the work of the members so that the members' motivation increases (Saggaf et al., 2014; Ismail et al., 2016). This will have an impact on providing maximum services to the community. The biggest challenge today is that there is a perception to the governmental organizations that they are slow, intricate, and full of corruption, collusion and nepotism in providing services to the community (Nurbarani 2009; Saputra 2014; Jamaluddin et al., 2017).

One outcome of the village fund corruption monitoring carried out by members of the Bhabinkamtibmas at the Bungo - Jambi Police in 2018 and 2019 was when a criminal act of corruption on behalf of AZ was identified. The perpetrator violated Article 2, paragraph 1 and Article 3 of the Law of the Republic of Indonesia 
Number 31/ 1999 in conjunction with the Law of the Republic of Indonesia Number 20/ 2001 regarding Criminal Act of Corruption in conjunction with Article 55 of the Criminal Code. This is an achievement of Bhabinkamtibmas officers who strived in realizing good and clean governance, and providing public services (Azizy, 2007). Such achievement is in line with the results of several researches revealing that several factors in the culture of organization can affect employee performance (Dharma \& Akib, 2009; Jamaluddin et al., 2017). In addition, other researches also show that work motivation has a significant effect on employee performance (Sutadji, 2008; Oluyesi, 2009; Nurcahyani, 2016); the provision of positive motivation affects the level of employee performance.

With the current organizational culture, it is hoped that it can increase the motivation of Bhabinkamtibmas members in completing their duties and responsibilities. Therefore, their performance will also improve. The presence of Bhabinkamtibmas members is very important as the front-line of maintaining security and order in the community by taking initial action in handling the problem of village fund corruption.

Based on this background, the formulation of the problem in this study is how the influence of organizational culture and motivation can improve the performance of Bhabinkamtibmas members. The purpose of this study is to determine the effect of organizational culture and work motivation on the performance of Bhabinkamtibmas, either partially or simultaneously. The results of this study are expected to increase the motivation and performance of members of Bhabinkamtibmas with the existing organizational culture. In addition, this research can be used as material for analysis and evaluation for the police institution to give appreciation to the work of the members of Bhabinkamtibmas as the front-liner in providing services to the community.

\section{STUDY OF THEORY}

\subsection{Organizational culture}

Organizational culture is related to subjective aspects in organization that have significant influence on a person's behaviour, emotion and psychology (Osborne and Plastrik, 2007: 77). Organizational culture is an organizational structure that is rooted in the values of beliefs and assumptions (Greenberg, 2003). Arianty's (2014) research also shows that organizational culture is related to values, norms, attitudes and work ethics. The main characteristics of organizational culture are initiative, tolerance for risk, integration, management support, control pattern, identity, reward system, tolerance for conflict, and the existence of communication pattern (Robbins, 1994: 76). To implement a suitable organizational culture in an organization, support and participation of members in the organization is needed (Jamaluddin et al, 2017). Organizational culture can be developed by doing external adaptation and internal integration (David, 2004). Sabri (2011) defines organizational culture indicators as 
openness, mutual respect and cooperation.

\subsection{Motivation}

Motivation is a psychological process that awakens and directs one's behaviour to achieve goals (Kreitner and Kinicki, 2001: 378). According to Latham \& Pinder (2005), motivation is a process that occurs continuously that will affect a person's behaviour. Santoso (2012) states that a person will behave better if there is intrinsic and extrinsic motivations. This motivational drive will give a person strength to face and solve complex problems in different ways. Thus, someone's motivation will affect the way he or she behaves and works (Hanafi, 2017). Furthermore, Asa'ad (2010) states that motivation is the strength of a person to struggle through critical times and strive to get better results than before. Uno (2008) describes work motivation indicators as desire for achievement, recognition, and appreciation.

\subsection{Performance}

Performance is defined as an extra role, such as cooperation, helping colleagues and superiors, and general trend towards compliance. Performance is the achievement from the implementation of certain tasks (Payaman, 2005). Harsuko (2011) defines performance as behavior of doing something related to work. Performance as a result of employee's work is shown in accordance with his or her role in organization (Hariandja, 2008). This is in accordance with the results of Arianty's (2014) research showing that performance is the result of work achieved by a person or group in an organization which is in line with their respective responsibilities in achieving organizational goals. Dessler (2007) reveals several factors that affect performance, namely motivation, job satisfaction, stress levels, physical conditions of work, compensation system, job design, organizational commitment, and economic aspects. Conforming what Kiruja (2013) states, an employee's performance is the functions of ability and motivation. Stephen Robin in Pasolong (2007: 176) reveals that performance is the result of an evaluation of the work that has been done based on predetermined criteria. It is explained in the human resource management that performance can be measured using various criteria, including supervision, productivity index, promotion capability, total sales, and turnover. This is confirmed by Robbins (2009) who develops performance indicators as quality of work, quantity of work, and timeliness.

\subsection{Research Hypothesis}

The research hypotheses are formulated as follow:

- H1: there is an influence of organizational culture on the performance of members of Bhabinkamtibmas of Bungo Resort Police. 
- H2: there is an influence of motivation on the performance of members of Bhabinkamtibmas of Bungo Resort Police.

- H3: there is an influence of organizational culture and motivation on members of Bhabinkamtibmas of Bungo Resort Police.

\section{RESEARCH METHODOLOGY}

The research approach used is quantitative with survey method. The variables studied are organizational culture (X1), work motivation (X2) and performance $(\mathrm{Y})$. The population in this study are 53 members of Bhabinkamtibmas who served in the Bungo Resort Police jurisdiction, using total sampling (Santoso \& Tjiptono, 2002: 80).

The research instrument was compiled and developed from three research variables which fall into several indicators. Each variable contains 3 indicators, then each indicator is developed into 15 statement items. Total statements of 45 items. The measuring instrument used is Likert scale, with a scale range of answer choices 1 to 5 (Sugiyono, 2015: 93).

The instrument test was used to measure the validity and reliability of the 45 statement items before collecting data in the field. Ghozali (2005: 45) states that validity measurement can be done by looking at the value of the Correlated ItemTotal Correlation with the following criterion: if the calculated $r$ value is greater than $r$ table and the value is positive, then the question item is said to be valid. In this study, the results of the measurement of the validity value of 15 items of variable X1, 15 items of $\mathrm{X} 2$, and 15 items of $\mathrm{Y}$ were declared valid with $r$-count $>$ r-table $=0.3610$, which were tested on 30 respondents. According to Nunnally (in Ghozali, 2005: 42), a questionnaire is said to be reliable if someone's answer to a question is consistent over time and results in Cronbach's Alpha value greater than 0.60 . From the calculation results, the Cronbach's Alpha value for each variable $\mathrm{X} 1$ is 0.975 for variable $\mathrm{X} 2$ is 0.983 and for variable $\mathrm{Y}$ is 0.983. This value indicates that the questionnaire is considered reliable because it is greater than 0.60 .

The data analysis technique began with the normality test, multicollinearity test, and heteroscedasticity test. Then, it was proceeded with multiple linear regression analysis, simultaneous and partial hypothesis testing, and coefficient determination using the SPSS (Statistic Package for Social Science) program version 21. For partial acceptance criteria, if the value of $\mathrm{t}$-count $>\mathrm{t}$-table, with a value of t-table $=2.008$ with $\alpha=0.05$. The simultaneous acceptance of the hypothesis is achieved if the value of F-count $>$ F-table with F-table value $=$ 3.18 with $\alpha=0.05$.

\section{RESULTS}

The research respondents were 53 members of Bhabinkamtibmas of Bungo Resort Police; the objects of research include respondents' age, gender, status, education, and years of service. From the tabulation result according to the age of the largest respondents in this study was between 
the ages of $31-40$ years as many as 27 people or $51 \%$ as seen in Table 1 , below:
Table 1

Respondents Based on Age

\begin{tabular}{ccc}
\hline Age & Frequency & Percentage \\
\hline$>50$ & 6 & $11 \%$ \\
\hline $41-50$ & 15 & $28 \%$ \\
\hline $31-40$ & 27 & $51 \%$ \\
\hline$\leq 30$ & 5 & $9 \%$ \\
\hline Source: & Ms. Excel 2020 Data Processing
\end{tabular}

Based on gender, the total number of respondents from the questionnaire data collected was 53 male or $100 \%$ as shown in Table 2:

Table 2

\begin{tabular}{ccc} 
& \multicolumn{2}{c}{ Respondents Based on Gender } \\
\hline Gender & Frequency & Percentage \\
\hline Male & 53 & $100 \%$ \\
\hline Female & - & $0 \%$ \\
\hline \multicolumn{3}{c}{ Source: Ms. Excel 2020 Data } \\
Processing
\end{tabular}

Based on marital status, the largest number of respondents in the study was married as many as 47 people or 89\% as shown in Table 3:

Table 3

Respondents Based on Marital Status

\begin{tabular}{ccc}
\hline Status & Frequency & Percentage \\
\hline Single & 6 & $11 \%$ \\
\hline Married & 47 & $89 \%$ \\
\hline Divorced & - & $0 \%$ \\
\hline & Source: Ms. Excel 2020 Data
\end{tabular}

Processing
Based on the level of education, the largest number of respondents in this study was at the high school / vocational school level as many as 40 people or $75 \%$ as shown in Table 4:
Table 4.

Respondents Based on Education

\begin{tabular}{ccc}
\hline Education & Frequency & $\begin{array}{c}\text { Percenta } \\
\text { ge }\end{array}$ \\
\hline $\begin{array}{c}\text { High School/Vocational } \\
\text { and equivalent }\end{array}$ & 40 & $75 \%$ \\
\hline Diploma & - & $0 \%$ \\
\hline Undergraduate & 13 & $25 \%$ \\
\hline Master -higher & - & $0 \%$ \\
\hline Source: Ms. Excel 2020 Data Processing
\end{tabular}

Based on the years of service in the police institution, the largest number of respondents in this study was 27 people or $51 \%$ during a period of more than 15 years, as shown in Table 5:

\section{Table 5}

Respondents Based on Years of Service

\begin{tabular}{ccc}
\hline Years of Service & Frequency & Percentage \\
\hline$>15$ years & 27 & $51 \%$ \\
\hline $15-11$ years & 17 & $32 \%$ \\
\hline $10-5$ years & 9 & $17 \%$ \\
\hline$<5$ years & - & $0 \%$ \\
\hline \multicolumn{3}{c}{ Source: Ms. Excel 2020} \\
Data Processing
\end{tabular}

In the statistical test for examining the first hypothesis, the influence of organizational culture on the performance of Bhabinkamtimas (X1 to $\mathrm{Y}$ ), the result shows that organizational culture affects the performance of Bhabinkamtibmas. The test results on the coefficient table show that the value of unstandardized coefficient B is 0.996 and the value is Sig. equal to 0.000 by comparing t- 
count and $\mathrm{t}$-table. If $\mathrm{t}$-count is $<\mathrm{t}$-table, it means that $\mathrm{H} 0$ is accepted and $\mathrm{H} 1$ is rejected $(\alpha=5 \%)$. If $\mathrm{t}$-count is $>\mathrm{t}$ table, it means that $\mathrm{H} 0$ is rejected and $\mathrm{H} 1$ is accepted $(\alpha=5 \%)$, with $\mathrm{df}=(\mathrm{n}-$ 3 ), then we get $(53-3)=50$, so that $\mathrm{t}$ table $=2.00856$, as shown in Table 6 .

From the data table above, the value of $\mathrm{t}$-count $>\mathrm{t}$-table or $(27.468>2.008)$ is obtained with a significance value of 0.000 . So, $\mathrm{H} 0$ is rejected and $\mathrm{H} 1$ is accepted; this shows that there is a positive and partially significant influence of Organizational Culture on Bhabinkamtibmas performance.
Furthermore, the coefficient of determination (R2) is used to measure the magnitude of the influence of the organizational culture variable on the performance of Bhabinkamtibmas of Bungo Resort Police. The obtained RSquare value (coefficient of determination) is 0.937 , so it can be concluded that the influence of the Organizational Culture variable (X1) on the Bhabinkamtibmas (Y) performance variable is $93.7 \%$ while the remaining $6.3 \%$ is influenced by other factors, as shown in Table 7.

Table 6.

t-Partial Test Results for $\mathrm{H1}$

\begin{tabular}{|c|c|c|c|c|c|c|}
\hline \multirow[b]{2}{*}{ Model } & & \multicolumn{2}{|c|}{$\begin{array}{l}\text { Unstandardized } \\
\text { Coefficients }\end{array}$} & \multirow{2}{*}{$\begin{array}{c}\text { Standardized } \\
\text { Coefficients } \\
\text { Beta }\end{array}$} & \multirow[b]{2}{*}{ t } & \multirow[b]{2}{*}{ Sig. } \\
\hline & & $B$ & Std. Error & & & \\
\hline 1 & (Constant) &,- 084 & 1,714 & & $\begin{array}{l}-.049 \\
\end{array}$ & .961 \\
\hline & $\begin{array}{l}\text { Organisational } \\
\text { Culture }\end{array}$ & .996 & .036 & .968 & 27,468 & .000 \\
\hline
\end{tabular}

a. Dependent Variable: Per formance

Table 7

Coefficients of Determination for $\mathrm{H} 1$

\begin{tabular}{|l|c|r|r|r|}
\hline Model & $\mathrm{R}$ & $\begin{array}{c}\mathrm{R} \\
\text { Square }\end{array}$ & $\begin{array}{c}\text { Adjusted R } \\
\text { Square }\end{array}$ & Std. Error of the Estimate \\
\hline 1 & $.968^{\mathrm{a}}$ &, 937 &, 935 & 2,780 \\
\hline
\end{tabular}

a. Predictors: (Constant), Organizational Culture

The results of second hypothesis testing is about the effect of work motivation on the performance of Bhabinkamtibmas (X2 to Y). The second hypothesis testing results state that work motivation has an effect on the performance of the Bhabinkamtibmas of Bungo Resort
Police, with a significance value of $5 \%$ $(0.05)$ comparing t-count and $t$-table. If $\mathrm{t}$-count is $<\mathrm{t}$-table, it means that $\mathrm{H} 0$ is accepted and $\mathrm{H} 1$ is rejected $(\alpha=5 \%)$. If $\mathrm{t}$-count is $>\mathrm{t}$-table, it means that $\mathrm{HO}$ is rejected and $\mathrm{H} 1$ is accepted $(\alpha=$ $5 \%)$, with $\mathrm{Df}=(\mathrm{n}-3)$, then we get $(53-$ $3)=50$, so that $\mathrm{t}$ table $=2.00856$, as shown in Table 8:

Table 8

t-Partial Test Results for $\mathrm{H} 2$

\begin{tabular}{|l|c|c|c|c|}
\hline Model & $\begin{array}{c}\text { Unstandardized } \\
\text { Coefficients }\end{array}$ & $\begin{array}{c}\text { Standardized } \\
\text { Coefficients }\end{array}$ & $\mathrm{t}$ & Sig. \\
\hline
\end{tabular}




\begin{tabular}{|c|c|c|c|c|c|}
\hline & B & Std. Error & Beta & & \\
\hline $1 \quad$ (Constant) & 2,439 & 2,367 & & 1,030 & .308 \\
\hline $\begin{array}{l}\text { Work } \\
\text { Performance }\end{array}$ & .956 & .051 & .935 & 18,819 & .000 \\
\hline
\end{tabular}

a. Dependent Variable: Performance

The results of the coefficients show that the value of unstandardized coefficient B was 0.956 with the Sig. equal to 0.000 and the value of $t$-count is $>\mathrm{t}$-table or $(18.819>2.008)$. Thus, $\mathrm{HO}$ is rejected and $\mathrm{H} 1$ is accepted, indicating that there is a partially positive and significant influence of work motivation on the performance of community services police.

The coefficient of determination $\left(\mathrm{R}^{2}\right)$ is used to measure the magnitude of the influence of the work motivation variable on the performance of Bhabinkamtibmas officers. The RSquare value (coefficient of determination) is 0.874 ; it can be concluded that the influence of the work motivation variable (X2) on the Bhabinkamtibmas (Y) performance variable is $87.4 \%$ while the remaining $12.6 \%$ is influenced by other factors, as shown in Table 9.

Table 9

Coefficients of Determination for $\mathrm{H} 2$

\begin{tabular}{|c|c|c|c|c|}
\hline Model & $\mathrm{R}$ & $\begin{array}{c}\mathrm{R} \\
\text { Square }\end{array}$ & $\begin{array}{c}\text { Adjusted R } \\
\text { Square }\end{array}$ & Std. Error of the Estimate \\
\hline 1 & $.935^{\mathrm{a}}$ & .874 & .872 & 3,920 \\
\hline
\end{tabular}

a. Predictors: (Constant), Work Motivation

The testing results of the third hypothesis is on the influence of organizational culture (X1) and work motivation (X2) on the performance of Bhabinkamtibmas (Y). The third hypothesis testing results indicate that organizational culture and work motivation have effect on the performance of Bhabinkamtibmas. The results of the coefficients show that the value of unstandardized coefficient $B$ for constant is -0.406 with a significant value of 0.810 , thus $\mathrm{H} 1$ is accepted, but the result is not significant, with the regression equation $\mathrm{Y}=-0.406+$
$0.805 \mathrm{X} 1+0.201 \mathrm{X} 2$. This equation implies that if the organizational culture (X1) increases by one unit, the performance of the community services (Y) will increase by 0.805 unit, assuming that the other variables are constant. If work motivation (X2) increases by one unit, the performance of Bhabinkamtibmas (Y) will increase by 0.201 unit, assuming that the other variables are constant. In general, from this equation model, it is predicted that organizational culture and work motivation have positive value on performance. 
Work Motivation $\left(X_{2}\right)$ on Performance $(Y)$

\begin{tabular}{|c|c|c|c|c|c|c|c|}
\hline \multirow[b]{2}{*}{ Model } & \multicolumn{2}{|c|}{$\begin{array}{l}\text { Unstandardize } \\
\text { d Coefficients }\end{array}$} & \multirow{2}{*}{$\begin{array}{c}\begin{array}{c}\text { Standardized } \\
\text { Coefficients }\end{array} \\
\text { Beta } \\
\end{array}$} & \multirow[b]{2}{*}{$\mathrm{t}$} & \multirow[b]{2}{*}{ Sig. } & \multicolumn{2}{|c|}{$\begin{array}{l}\text { Collinearity } \\
\text { Statistics }\end{array}$} \\
\hline & B & $\begin{array}{l}\text { Std. } \\
\text { Error }\end{array}$ & & & & Tolerance & VIF \\
\hline 1 (Constant) & $\begin{array}{c}- \\
406\end{array}$ & 1,681 & &,- 241 & ,810 & & \\
\hline Org. Behaviour & ,805 & , 107 & ,782 & 7,518 & ,000 & 109 & 9,158 \\
\hline Work Motivation & ,201 & ,106 & , 197 & 1,892 & ,064 & , 109 & 9,158 \\
\hline
\end{tabular}

a. Dependent Variable: Performance

Simultaneous testing is intended to test the effect of organizational culture variable and work motivation on the performance of Bhabinkamtibmas using $\mathrm{F}$ statistical test. With the significance $(\alpha=5 \%)$ or 0.05 and degrees of freedom (df) and with the formula $\mathrm{df}=\mathrm{nk}-1$, where $\mathrm{n}$ is the number of respondents and $\mathrm{k}$ is the number of variables studied and comparison between the value of $\mathrm{F}$ count and F-table, if F-count is < Ftable, then $\mathrm{H} 0$ is accepted and $\mathrm{H} 1$ is rejected $(\alpha=5 \%)$. If F-count is > Ftable then $\mathrm{H} 0$ is rejected and $\mathrm{H} 1$ is accepted $(\alpha=5 \%)$, with df (N2) $=53$ $2-1$ and df $(\mathrm{N} 1)=2$, so F-table $=3.18$, as shown in Table 11:

Table 11

f-Simultaneous Test for $\mathrm{H3}$

\begin{tabular}{|c|c|c|c|c|c|}
\hline Model & Sum of Squares & df & Mean Square & $\mathrm{F}$ & Sig. \\
\hline 1 Regression & 5858,229 & 2 & 2929,114 & 398,102 & $.000^{\mathrm{b}}$ \\
\hline Residual & 367,885 & 50 & 7,358 & & \\
\hline Total & 6226,113 & 52 & & & \\
\hline
\end{tabular}

a. Dependent Variable: Performance

b. Predictors: (Constant), Work Motivation, Organizational Culture

variables on the performance of The results of the calculation obtain the value of F-count > F-table or $(398,102>3.18)$ with a significance of 0,000 . Thus, $\mathrm{H} 0$ is rejected and $\mathrm{H} 1$ is accepted; this indicates that there is a positive and significant simultaneous influence between organizational culture and work motivation on the performance of Babhinkamtibmas of Bungo Resort Police.

The coefficient of determination $\left(\mathrm{R}^{2}\right)$ is used to measure the influence of the organizational culture and motivation

Table 12

Coefficient of Determination for $\mathrm{H3}$

\begin{tabular}{|l|l|r|r|r|}
\hline Model & R & $\begin{array}{c}\text { R } \\
\text { Square }\end{array}$ & \multicolumn{1}{c|}{$\begin{array}{c}\text { Adjusted R } \\
\text { Square }\end{array}$} & Std. Error of the Estimate \\
\hline 1 & $.970^{\mathrm{a}}$ & .941 & .939 & 2,713 \\
\hline
\end{tabular}

a. Predictors: (Constant), Work Motivation, Organizational Culture 


\section{DISCUSSION}

\subsection{The Influence of Organizational Culture on Performance}

The condition of the police organization gives colour to the work culture of police officers, especially members of Bhabinkamtibmas Unit. The contribution of Bhabinkamtibmas members as the front-liner of service providers to the community will be influenced by the habits or existing work rules which become work culture. The work culture in an organization, according to Sabri (2011) has three characteristics, namely openness, mutual respect, and cooperation. Openness is the clarity in the implementation of tasks that become the responsibility of the members. Mutual respect is about understanding the burden of tasks that must be completed and carried out. Cooperation is the contribution to the completion of tasks and responsibilities at the predetermined time. If the organizational culture is good, it will improve the employee performance and give positive contribution to the success of the company (Arianty, 2014).

During the Covid-19 pandemic, the duty burden or work load of the members of Bhabinkamtibmas has indirectly increased. Apart from being the front-liner in providing direct services to the community and controller of the use of village fund which is a big amount, they have extra duties as Covid-19 response village task force. There is a concern that the possibility of the village fund budget manipulation under the reason of strengthening the response to Covid-19 may vulnerably happen, for example in providing assistance for personal security, strengthening food security, providing cleaning tools, and other allocations that allow fund to be disbursed. In this case, Bhabinkamtibmas as a partner is expected to prevent any act of corruption as early as possible due to the manipulation of village fund. Prevention efforts carried out by Bhabinkamtibmas are closely related to the members' loyalty which is reflected in their performance. Performance can be implemented if the elements in the organizational culture can be fulfilled, including values, norms, artefacts and management styles (Ismail, 2013). In this case, the value factor is related to the assessment of an activity, norms are defined as unwritten rules that must be respected, artefacts represent tangible aspects of an organization, and management style is an approach used by leaders to communicate with others.

This is supported by the results of research calculations, where the results of the hypothesis test obtain $\mathrm{t}$-count $>\mathrm{t}$-table $(27.468>2.008)$ with a significance value of $0.000<0.05$. Thus, H0 is rejected and $\mathrm{H} 1$ is accepted, that there is a partially 
positive and significant influence of organizational culture on Bhabinkamtibmas performance. The R2 results of the organizational culture variable (X1) on the performance of Bhabinkamtibmas (Y) is 0.937 or $93.7 \%$ and the remaining $6.3 \%$ is influenced by other factors. This shows that high organizational culture will improve the performance of Bhabinkamtibmas.

Overall, the results of this study are in line with Ashraf and Rezaie's (2015) research publication that there is a relationship between organizational culture and performance in the Islamic Azad University faculty in Iran with a total sample of 358 personnel and the results of research by Jamaluddin et al., (2017) that show an influence of organizational culture on employee performance in the education office of South Sulawesi Province with a population of 235 employees.

\subsection{The Influence of Work Motivation on Bhabinkamtibmas Performance}

Motivation is the driving force of a person to take an action in order to do activities or solve problems in different ways. Motivation can occur intrinsically (appreciation and recognition) and extrinsically (remuneration, duties and responsibilities, obedience to rules that are not rigid) (Sutrisno, 2013). Bhabinkamtibmas members who have positive motivation will carry out their duties more comfortably and will produce better work results, although there are often additional tasks outside the main task which is providing services to the community, which one of them is being part of the Covid-19 response village task force. The motivation of Bhabinkamtibmas members aims at completing their responsibilities better so that they can improve their work outcomes by paying attention to the work facilities provided, so that it can lead to job satisfaction (Rantihusna, 2010). The facilities provided are not only for the members, but also for their families. This is in line with what Uno (2008) states that indicators of employee motivation in carrying out tasks include: appreciation, desire for achievement, and recognition. For example, leadership's appreciation for the employee's work as a form of achievement is also leadership's appreciation for his family for giving him support.

From the results of the hypothesis test, it is obtained that $\mathrm{t}-$ count is > t-table or $(18,819>$ $2,008)$ with a significance of 0.000 $<0.05$. Thus, $\mathrm{H} 0$ is rejected and $\mathrm{H} 1$ is accepted, meaning there is a partially positive and significant influence between work motivation and community services and public order performance. The results of the R2 variable of work motivation (X2) on the performance of Bhabinkamtibmas $(\mathrm{Y})$ is 0.874 or equal to $87.4 \%$ and the remaining $12.6 \%$ is influenced by other 
factors. This shows that high work motivation will improve performance.

The results of this study are in line with several research publications (Chintallo; Uzonna, 2013; Omollo, 2015) revealing that the higher the motivation, the higher the performance, supported by work facilities. In this case, the leadership/ company can find ways to continue to grow and increase motivation and so that it can improve performance.

\subsection{The Influence of Organizational} Culture (X1) and Work Motivation (X2) on Bhabinkamtibmas Performance (Y)

The results of the research calculations show that organizational culture (X1) and work motivation (X2) simultaneously have positive effect on the performance of the members of Bhabinkamtibmas Bungo Resort. The regression equation obtained is $\mathrm{Y}=-0.406+0.805 \mathrm{X} 1$ $+0.201 \mathrm{X} 2$. This means that the constant value $=-0.406$ and $\mathrm{a}$ significant value of 0.810 means that $\mathrm{H} 1$ is accepted, but the results are not significant. The coefficient of the organizational culture variable is 0.805 and the work motivation variable is 0.201 . The better the organizational culture and work motivation, the better the performance of Bhabinkamtibmas at the Bungo Police. On the other hand, the worse the organizational culture and work motivation, the lower the performance of
Bhabinkamtibmas Bungo Resort Police.

Hypothesis testing is obtained using statistical tests with the criterion F-count > F-table $(398.102>3.18)$, so that $\mathrm{HO}$ is rejected and $\mathrm{H} 1$ is accepted. This means that there is a positive and significant simultaneous influence of organizational culture and work motivation on the performance of Bhabinkamtibmas of Bungo Resort Police. The contribution of the influence of organizational culture and work motivation is 0.941 or $94.1 \%$ while the remaining $5.9 \%$ is influenced by other factors.

From the findings, it can be explained that organizational culture can affect a person's performance, and this will usually lead to individual motivation. If there is positive motivation in the individual, it will affect the results of job appraisals. Performance appraisal is not only to know how well the employee has performed his work, but also concerns the level of wage and direction of tasks to be completed (Byars and Rue, 2006). The performance of members of Bhabinkamtibmas Bungo Resort Police can be described in terms of quality, timeliness, and quantity of work. In the end, it is hoped that an open organizational culture, mutual respect, and good cooperative relationships will be created.

Giving motivation can also affect a person's performance level (Oluyesi, 2009; Aprilia, 2012). Positive work motivation will tend to have high enough performance, 
because a person's behaviour depends on the motivation he or she has. If the members of Bhabinkamtibmas have positive motivation, they will be eager to excel in carrying out and completing the tasks that are their responsibilities. Conversely, if the motivation is low, then the tendency is in completing the work and it results in low performance and organizational goals are not achieved. And to be able to create an appropriate organizational culture within an organization, support from all members in the organization is needed.

\section{CONCLUSIONS}

It can be concluded that there is a positive influence between organizational culture and work motivation on members' performance. Members of Bhabinkamtibmas of Bungo Resort Police have strong performance and seek to increase positive motivation by creating healthy organizational culture, so they can provide maximum services to the community in the effort of early detection to prevent the corruption of village fund.

\section{IMPLICATIONS}

The next action is that the organization must be able to pay more attention and give appreciation to the performance of the members in carrying out their duties as well as create a conducive organizational climate that results in healthy organizational culture and increasing motivation of the members in order to provide maximum services to the community.

\section{REFERENCES}

Agung, 2015, Implementasi Alokasi Dana Desa (ADD) dalam meningkatkan pembangunan desa Liang Butan Krayan Kabupaten Nunukan, ejournal Administrasi Negara, FisipUnMul, Vol. 3 No. 5, p. 109-121.

Aprilia, Murty Windy., Hundiwinarsih Gunasti., 2012, Pengaruh Kompensasi, Motivasi dan Komitmen Organisasi terhadap Kinerja Karyawan Bagian Akuntansi (Studi Kasus pada Perusahaan Manufaktur di Surabaya). Jurnal The Indonesian Accounting Review, Vol.2, No. 2, p. 215-228.

Arianty, Nel. 2014, Pengaruh Budaya Organisasi Terhadap Kinerja Pegawai, Jurnal Managemen \& Bisnis Vol.14 No.02 Oktober 2014 ISSN 1693-7619, p. 144-150.

As'ad, M., 2010, Kepemimpinan Efektif dalam Perusahaan, Edisi 2. Yogyakarta: Liberty.

Ashraf, Giti dan Mohammd Hassan Rezaie. 2015. Organizational Culture: A Predictor of Faculty Members' Job Satisfaction. British Journal of Education, Vol. 3, No.8, Agustus 2015, p.1-9.

Azizy, A. Q. A, 2007, Change Management dalam Reformasi Birokrasi, Jakarta: Gramedia Pustaka Utama.

Brahmasari, Ida Ayu. 2005, Pengaruh Variabel Budaya Perusahaan terhadap Komitmen Karyawan dan Kinerja Perusahaan Kelompok Penerbitan Pers Jawa Pos, Disertasi Universitas Airlangga, Surabaya. 
Ekuitas ISSN 1411-0393. Akreditasi No.49/DIKTI/Kep/2003. Ekuitas Vol.9 No.2 Juni 2005, p.145-168.

Byars dan Rue, 2006. Jones and Bartlett

Learning, LLC. http://samples.jbpub.com/9781449653 293/27829_CH01_003_032.pdf.

Chintalloo, S., (n.d). Effect of Motivation on Employee's Work Performance at Ireland Blyth Limited, London Business Research Conference Imperial Collage, p.1-16.

Dharma, S., \& Akib, H. 2009. Kewirausahaan Sekolah Berbasis Kreativitas dan Inovasi. Jurnal Pendidikan dan Kebudayaan, Edisi Khusus, p. 102-117.

Dessler, G. 2007. Sumber Daya Manusia. Jakarta: Indeks.

Greenberg, J. And Robert A. Baron. 2003. Behavior in Organization International Edition, New Jersey: Prentice Hall.

Ghozali, Imam. 2012. Aplikasi Analisis Multivariate dengan Prgram IBM SPSS 19 (Edisi kelima), Universitas Diponegoro, Semarang.

Hamzah, B Uno. 2008. Teori Motivasi \& Pengukurannya. Jakarta: PT. Bumi Aksara Hanafi, Bayu Dwilaksono., \& Corry Yohana. 2017. Pengaruh Motivasi dan Lingkungan Kerja terhadap Kinerja Karyawan dengan Kepuasan Kerja sebagai Variabel Mediasi pada PT BNI Lifeinsurance. Jurnal Pendidikan Ekonomi dan Bisnis (JPEB) Vol.5 No.1 Maret 2017. DOI: doi.org/10.21009/JPEB.005.1.6. EISSN:2302-2663, p.73-89.

Harsuko, 2011. Manajemen Sumber Daya Manusia Perusahaan, Jakarta : Rosda.
Hasibuan, Malayu, S.P., 2006. Organisasi dan Motivasi Dasar Pendekatan Produktivitas. Cetakan Keempat, Jakarta: PT. Bumi Aksara.

Indonesia, 2002, Undang-Undang Nomor 2 Tahun 2002 Tentang Kepolisian Negara Republik Indonesia, Jakarta.

Ismail, A., Sulur, A.H., Akib, H., \& Salam, R., 2016. Snapshot of Society Social-Economic Welfare based on Human Development Index in Polewali Mandar Regency, Indonesia. In International Conference on Public Organization VI (ICONPO VI). Thammsat University, Tha Prachan Campus, p. 847-858.

Ismail Nawawi. 2013. Budaya Organisasi Kepemimpinan \& Kinerja. Jakarta: Prenadamedia Group

Jamaluddin., Rudi Salam., Harisman Yunus., \& Haedar Akib., 2017. Pengaruh Budaya Organisasi terhadap Kinerja Pegawai pada Dinas Pendidikan Provinsi Sulawesi Selatan. Jurnal Administrare: Jurnal Pemikiran Ilmiah dan Pendidikan Administrasi Perkantoran, Vol.4, No.1, p. 25-34.

Kiruja, E. K., 2013. Effect of Motivation on Employee Performance In Public Middle Level Technical Training Institutions in Kenya. International Journal of Advances in Management and Economics, 2, p.73-82.

Kreitner, R., \& Kinicki, A., 2001. Organizational Behavior, Fifth Edition. International Edition: Mc Graw-Hill Companies, Inc.

Latham, P. G., \& Pinder, C.C., 2005. Relationship Between Reward and Employee's Motivation in the NonProfit Organizations of Pakistan. Business Intelligence Journal. 
Nurbarani, M., 2009. Reformasi Birokrasi Pemerintah Kota Surakarta. Universitas Diponegoro.

Nurcahyani, Ni Made., \& I.G.A Dewi Adnyani., 2016. Pengaruh Kompensasi dan Motivasi terhadap Kinerja Karyawan dengan Kepuasan Kerja sebagai Variabel Intervening. E-Jurnal Manajemen Unud, Vol. 5, No. 1, ISSN: 2302-8912, p. 500-532.

Oluseyi, A. Shadare dan T, Ayo Hammed., 2009. Influence of Work Motivation, Leadership Effectiveness and Time Management on Employees Performance in Some Selected Industries in Ibadan, Oya State, Nigeria: Eropean Journal of Economic Finance. Bandung: Remaja Rosdakarya Offset.

Omollo, P.A., 2015. Effect of Motivation on Employee Performance of Commercial Bank in Kenya: A Chas Study of Kenya Commercial Bank in Migori Country. International Journal of Human Resoursces Studies, Vol.5, p. 87-103.

Osborne, David., dan Peter Plastrik, 2000. Memangkas Birokrasi: Lima Strategi Menuju Pemerintahan Wira Usaha, Edisi Terjemahan, Jakarta: PPM.

Pasolong, Harbani. 2007. Teori Administrasi Publik. Bandung: Alfabeta.

Ranihusna, Desti., 2010. Efek Rantai Motivasi pada Kinerja Karyawan. Jurnal Dinamika Manajemen, JDM Vol.1, No. 2, ISSN 2086-0668, EISSN 2337-5434, p. 90-103.

Robbins, P Stephen, 2009. Perilaku Organisasi. Penerbit Salemba Empat. Jakarta.

Sabri, P. S. U., Muhammad Ilyaz, dan Zahra Amjad. 2011. Organizational
Culture and Its Impact on the Job Satisfaction of the University Teachers of Lahore.International Journal of Business and Social Science Vol. 2 No. 24, p.121-128.

Saggaf, S., Salam, R., Kahar, F., \& Akib, H., 2014. Pelayanan Fungsi Administrasi Perkantoran Modern. Jurnal Ad'ministrare, 1 (1), p. 20-27.

Santoso, Singgih., dan Fandy Tjiptono, 2002. Riset Pemasaran Konsep dan Aplikasi dengan SPSS. Jakarta: PT. Gramedia Pustaka Utama.

Santoso, Were M. 2012. Influence of Motivation on Performance in the Public Security Sector with a Focus to the Police Force in Nairobi, Kenya. International Journal of Business and Social Science. Vol. 3 No. 23; December 2012, p. 195-204.

Saputra, B., 2014. Penguatan Peran Birokrasi dalam Meningkatkan Kualitas Pelayanan Publik di Wilayah Perbatasan Indonesia-Malaysia (studi di wilayah Sebatik Kabupaten Nunukan Kalimantan Utara). UNPAS.

Sugiyono. 2014. Metode Penelitian Kuantitatif Kualitatif dan R\&D. Bandung: Alfabeta

Sutadji. 2008. Pengaruh Kebijakan Sistem Kompensasi dan Kondisi Kerja serta Kapasitas Individu terhadap Motivasi Kerja dan Kinerja Karyawan PT. Telekomunikasi. Tbk. Difre VI Kalimantan. Disertasi Universitas Airlangga Surabaya.

Sutrisno, Edy. 2010. Manajemen Sumber Daya Manusia. Jakarta : Edisi Pertama, Cetakan Kedua, Kencana.

Uzonna, U.R., 2013. Impact of Motivation on Employee Performance: A case 
Study of Credit West Bank Cyprus. Journal of Economic and International Finance, Vol.5, p. 199-211.

Warsono,Hadi dan Ruksamin. 2014. The Obstacles of Implementation of Village Allocation Fund Program in the North Konawe Southheast Sulawesi. Diponegoro University: Indonesia. Journal of Management and Sustainability, Vol.4, No.3. ISSN 1925-4725 E-ISSN 1925-4733. Published by Canadian Center of Science and Education, p. 175-183. 